УДК 338.24 .01

JEL O12, O14, O32

DOI: $10.17213 / 2312-6469-2021-4-39-48$

\title{
PROBLEMS OF ASSESSING THE POTENTIAL FOR COMMERCIALIZATION OF SCIENTIFIC INNOVATIONS
}

\author{
(C) Alovsat G. Aliyev 2021
}

\section{Institute of Information Technology of Azerbaijan National Academy of Sciences}

The article is devoted to the problems of assessing the potential for the commercialization of scientific innovations. Features of development and application of scientific innovations, socio-economic features of innovative activity are studied. The implementation of infrastructure projects based on modern technologies in the liberated territories, as well as the importance of the e-Karabakh program were highlighted. A structural analysis model of the analysis stage of the application of scientific innovations to the market has been proposed. The directions of solving the problems of the transfer and commercialization of innovative technologies have been studied. Various approaches used to evaluate the components of the National Innovation System have been explored. Preliminary indicators characterizing the process of commercialization of scientific innovations have been developed, indexes forming a composite index of commercialization potential have been proposed. Recommendations on the commercialization of scientific innovation products, know-how, knowledge, ideas have been developed. Recommendations for the management of the process of commercialization of scientific innovations, modern ICT technologies, 4.0 Industrial Revolution, etc. the main requirements and trends have been taken into account. These recommendations can help to organize the effective management of the process of commercialization of scientific innovations.

Keywords: digital transformation, innovation infrastructure, scientific innovations, assessing the potential for commercialization, technology transfer, 4.0 Industrial revolution.

\section{Introduction}

The formation of scientific-technological innovation policy is one of the key issues in the development of economies in developed countries [1]. Digital transformation of the economy and society has become one of the priority issues facing the country in recent years. The development of the Internet network, which is the basis of ICT infrastructure, "Government Cloud", "Big Data", "Smart City", "Smart Village" and others [2]. It is planned to implement promising digital projects such as Consistent reforms are being carried out to turn Azerbaijan into a digital center in the region.

The development of "Industry, innovation and infrastructure", one of the UN Sustainable Development Goals 2030 [3], the application of the elements of 
the IV Industrial Revolution [4] in the activities of enterprises has become one of the main directions in the development of the world economy. The sustainability and effectiveness of economic reforms in Azerbaijan in this direction are enshrined in the National Priorities for Socio-Economic Development of Azerbaijan adopted in 2021 [5] and the Strategic Roadmaps for the development of the country's economy [6]. In order to support the implementation of this work, the Transfer Center for Technology Commercialization was established in the Republic [7]. The function of this center is to establish a link between science and industry, to establish mutual order and supply relations, to transfer technologies to increase the quality and application of inventive activity, and to commercialize the results of intellectual activity. The Transfer Center promotes the commercialization of scientific innovations and the introduction of technologies and projects to world markets. The creation of a favorable environment for the development of innovative entrepreneurship, the development of science-based products, technologies, as well as the creation of technoparks of various profiles, technology transfer centers continues [7].

Therefore, it is considered that the timely solution of issues of innovation and commercialization of innovative processes is of special importance in the establishment of the National Innovation System at the national level and the organization of its effective operation. For this reason, the article presents some recommendations on the problems of assessing the commercialization potential of scientific innovations.

\section{Features of development and application of scientific innovations}

The main goals of state policy in the field of science include ensuring the sustainable and systematic development of science, bringing the institutional system and funding mechanisms of scientific activity in line with world standards [8].

The state policy in the field of scientific innovation is to form the state innovation system and determine the strategic directions of its development, to create and develop scientific innovation entities, technopolises, science technology parks, technology incubators, innovation funds, innovation information banks. In this regard, scientific organizations have special responsibilities in the context of complex measures taken by the state in the country's economy, especially in the liberated territories. At present, the restoration of complex scientific research in these areas, the implementation of new scientific, innovative infrastructure projects based on modern technologies, the widespread use of information technology, as well as certain work within the framework of E-Karabakh has become an important issue for the country.

One of the main tasks ahead is to create "smart" cities and villages, intelligent systems, and infrastructure in the liberated post-conflict areas. In order to contribute to the systematic activities to be carried out in the country on the development of rehabilitation programs for these liberated areas, proposals 
and recommendations on complex programs were given in many scientific institutions. Development Program for 2020-2025 4.0 Comprehensive study of the processes taking place in the emerging socio-technological society under the influence of the industrial revolution and artificial intelligence technologies, etc. covered the development of research areas such as [9]. Fundamental research of scientific-innovative-production activity, applied research, production of innovative products, etc. can be shown as stages.

\section{Socio-economic features and efficiency of scientific innovative activity}

According to the Organization for Economic Co-operation and Development (OECD) [10], innovation is any new or somewhat improved product (product or service) or process applied, a new marketing method or a new organizational method in business practice, jobs or is the organization of foreign relations. Innovative activity is the application of new ideas, scientific knowledge, technology, and products to various areas of production and management to ensure economic development and competitiveness. Innovation manifests itself materially in the form of a product or process [11, 12].

New knowledge and technologies are used in product innovations. Technological innovation has a significant impact on the activities of enterprises, as well as the results of the use of factors of production. Process innovation is the development of a new or significantly improved production method and technology. In the field of information systems, ICT, informatization processes, computer networks, telecommunications equipment, virtual environment, etc. Product and process innovations can be considered electronic innovations. This type of innovation is one of the main directions in the innovative development of the economy, business, education, science, social sphere, management [13].

Different levels and directions of innovation activity can be included: Level I - the result of fundamental research, a new scientific idea, "know-how". Level II - the result of applied research, a new scientific-applied idea, "knowhow". Level III - financing, commercialization. Level IV - the result of experimental design work, new product, technology, organization, and technological development of production. Level V - market, sales, innovation modification, diffusion, transfer, service, feedback $[14,15]$.

\section{Stages of commercialization of scientific innovations}

Commercialization of innovation is a type of activity that promotes the sale or sale of innovative products and services that are the result of innovation processes [16-20].

The process of commercialization of scientific innovation is, in a broad sense, the monetization of ideas. Its main forms can be shown as commercialization of innovations, technological transfer, diffusion of innovations.

The model of innovation commercialization includes the following stages, data: fundamental research (FR) data, FR analysis results, applied research (AR) 
data, AR analysis results, experimental-constructor works (ECW) data, ECW analysis results, product marketing phase, commercialization efficiency assessment, marketing research and competitiveness assessment phase, etc. (figure 1).

It should be noted that the results of the analysis of the commercialization of innovation have a decisive impact on the future application of innovation.

The process of effective management of the commercialization of scientific innovations includes the provision of state support, identification of financial sources, directions of attracting investments or other sources, involvement of other structures with interested and active financial support, selection of potential investors according to criteria, etc. composed of stages such as. The main stages of the commercialization of scientific innovation are presented as shown in figure 2 [21].

The process of commercialization of scientific innovations has great difficulties. The study and use of the experience of a number of Western countries help to improve the process of commercialization of innovations and the establishment of an innovative economy.

\section{innovations}

Directions for solving the problems of commercialization of

Lack of sufficient information content in the whole process of innovation development slows down the process of commercialization of innovation projects.

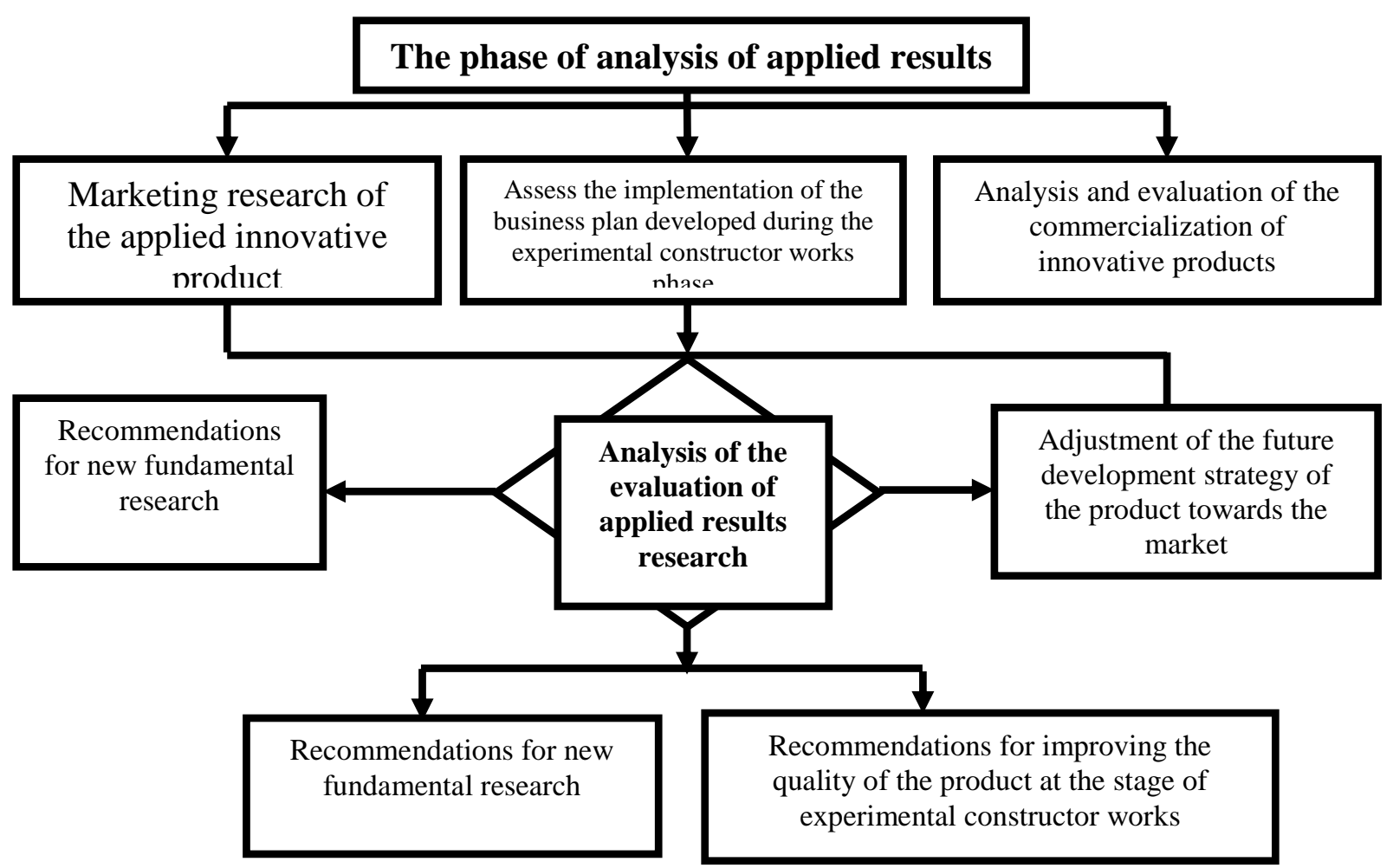

Figure 1. Structural analysis model of the Scientific Product marketing stage 


\begin{tabular}{|c|c|c|}
\hline $\begin{array}{c}\text { SELECTION AND } \\
\text { EVALUATION } \\
\text { STAGE } \\
\end{array}$ & $\begin{array}{c}\text { COMMERCIALIZATION, } \\
\text { COORDINATION-MONITORING } \\
\text { SCIENTIFIC RESEARCH CENTER }\end{array}$ & $\begin{array}{c}\text { FINANCLAL- } \\
\text { INVESTMENT SEARCH } \\
\text { STAGE } \\
\end{array}$ \\
\hline $\begin{array}{c}\text { Collection and } \\
\text { processing of } \\
\text { scientific ideas and } \\
\text { proposals }\end{array}$ & $\begin{array}{c}\text { A detailed comprehensive review of } \\
\text { the innovation project }\end{array}$ & $\begin{array}{l}\text { Financial resources } \\
\text { of the scientific } \\
\text { organization }\end{array}$ \\
\hline \multirow{2}{*}{$\begin{array}{l}\text { Analysis, expertise, } \\
\text { and evaluation of } \\
\text { innovation and } \\
\text { investment project }\end{array}$} & $\begin{array}{l}\text { University and business incubators, } \\
\text { innovative enterprises, innovation, } \\
\text { and technology center, transfer } \\
\text { center }\end{array}$ & $\begin{array}{l}\text { Government } \\
\text { agencies and } \\
\text { sponsoring } \\
\text { organizations }\end{array}$ \\
\hline & $\begin{array}{l}\text { Development of a business plan for } \\
\text { a commercial product }\end{array}$ & $\begin{array}{c}\text { Funds of joint } \\
\text { partners }\end{array}$ \\
\hline $\begin{array}{l}\text { Project selection and } \\
\text { decision making }\end{array}$ & $\begin{array}{l}\text { Production enterprise, experimental } \\
\text { field, experimental production, state }\end{array}$ & $\begin{array}{c}\text { University } \\
\text { development funds }\end{array}$ \\
\hline \multirow{2}{*}{$\begin{array}{l}\text { Assessment of the } \\
\text { innovative potential } \\
\text { of projects and } \\
\text { enterprises }\end{array}$} & $\begin{array}{c}\text { enterprise, innovative development } \\
\text { center }\end{array}$ & $\begin{array}{l}\text { Funds of venture } \\
\text { and other funds }\end{array}$ \\
\hline & Commercialization process & $\begin{array}{l}\text { Financial assistance } \\
\text { to the civil sector }\end{array}$ \\
\hline
\end{tabular}

Figure 2. The main stages of commercialization of scientific innovations

It is difficult to describe innovative technologies in the required way. This hinders the achievement of strategic goals [17]. The international level of commercialization of innovative technologies requires an innovator to feel the process of commercialization, to seek investment to produce a prototype of their product, to present, advertise and promote their new technology. In this process, some information about the problems of commercialization and their solutions can be given as shown in figure 3 .

Problems of transfer of innovative technologies. Lack of clarity for choosing the direction of the search at all stages of the work, from the search for technologies in the field of mastering and transfer of innovative technologies to their application and future accompaniment; the complexity of adequate commercial evaluation of other technologies; incomplete research, lack of projects close to serial production, lack of infrastructure for technology commercialization, etc. There are a number of different problems such as. The development of technology commercialization and transfer processes is of greater strategic importance $[18,22]$. The transfer of technologies is possible in the conditions of formation of an effective National Innovation System and intensive use of scientific and technical potential and its reproduction. The development experience of commercialization and transfer of technologies in developed countries should be taken into account, and the forms and methods of private-public cooperation should be improved to increase the efficiency of this process. 


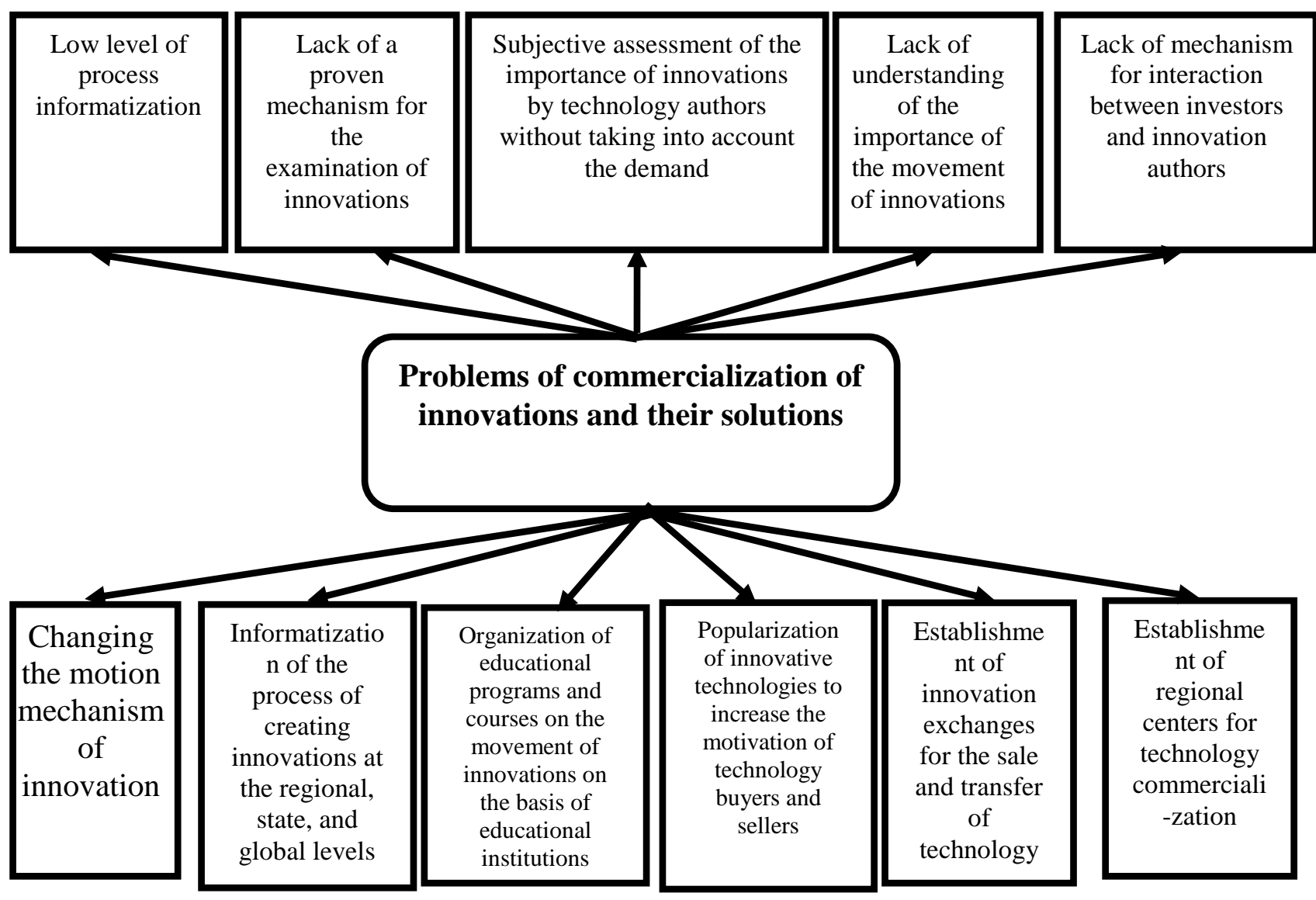

Figure 3. Directions for solving the problems of commercialization of innovative technologies

\section{Methodological bases of measuring innovation activity}

In world practice, different systems are used to evaluate the National Innovation System and its various components. The basic methodological principles of statistical measurement of innovation activity have been formed by the Industrial Development Fund of the Scandinavian countries. This document is known as the Oslo Methodology and was first published in 1992. This methodology was later improved by the Organization for Economic Cooperation and Development and the Statistical Service of the European Union and published in 1997, 2005, and 2018. International innovation statistics [23] are based on three methodologies of the Organization for Economic Cooperation and Development (OECD) and the European Union Statistical Service (Eurostat). The European scale of innovation [22] is a system of measurement of innovation environment, investments, investments in enterprises, building relationships on innovative activities, intellectual processes, sales tools, etc. composed of indicators such as.

Methodology for assessing the commercialization potential of scientific innovations

The following sub-indices and indicators were initially proposed to assess the commercialization potential of scientific innovations. The main level index 
is a proposed composite index of the commercialization potential (CP) of scientific results (projects) and consists of 10 second-level sub-indices. It is suggested that the composite index of the commercialization potential of scientific innovations be formed at the expense of the indices shown in figure 4 . The structure of the system of composite indexes of the commercialization potential of scientific innovations is proposed in a multi-level form. The main level integratively reflects all the lower levels that follow it, and the parameter that characterizes it is called the composite index of commercial potential (CCP).

The composite index is formed as a result of the assessment and has a leading position in the comparative analysis. Each sub-index is evaluated on a scale (0-10). Weight ratios are initially assumed to be 1 . The composite index is taken as the sum of the sub-indices and varies between (0-100).

In addition, the calculation of the $\mathrm{CP}$ composite index (CCP) can be functionally stated as follows:

$$
\text { CCP = F (EYI, PTO, XGY, INV, RES, MND, KUT, SFE, KDM, IMQ). }
$$

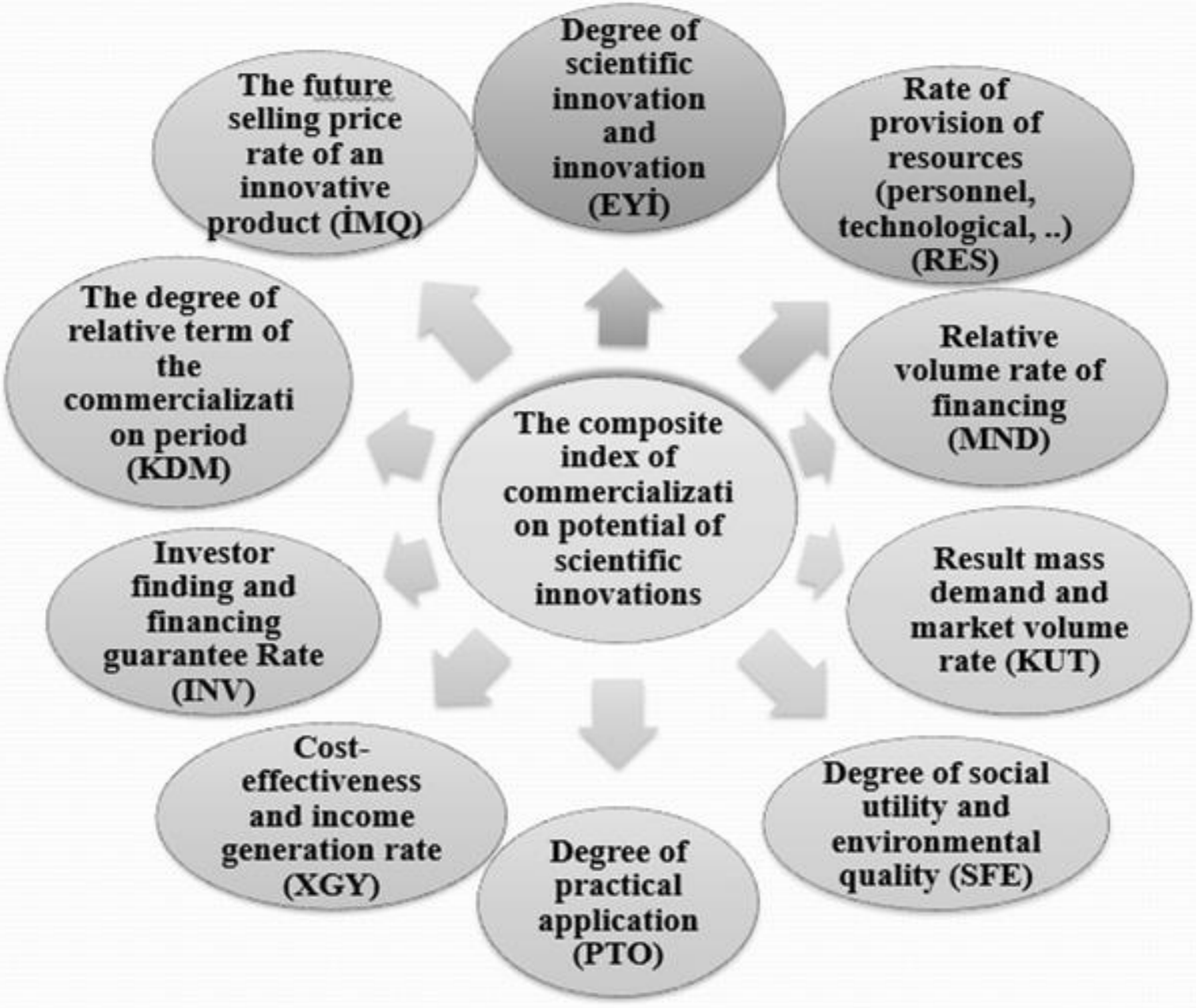

Figure 4. Indices that form a composite index of the commercialization potential of scientific innovations 
Here $\mathrm{F}$ is the form of dependence of the composite index on other indices.

The third level indicators are the prospects of commercialization, product quality, scientific and technical level, competitiveness, value, innovation, market potential, expediency, degree of uniqueness of work, reliability, resource availability, environmental and ecological qualities of work, material duration of work, the financial security of work, staffing of work, etc. about 50 [24, 25] indicators have been proposed.

Thus, research shows that the identification of problems in the commercialization of scientific innovations and attempts to solve them can create additional opportunities to increase the competitiveness of innovative, digital technologies and increase efficiency in sustainable economic development. For this reason, the development of recommendations in the relevant field and the development of mechanisms for their implementation is one of the necessary issues for the current period.

\section{Conclusion}

In modern times, the transformation of the economy on the basis of digital technologies, artificial intelligence, robotics, information and communication, space, etc. the development of technological areas such as is one of the main ways to achieve faster development of real economic sectors. Development of knowledge-based and innovation-based economy, production of science-based, ICT-based high-tech products, strengthening ties between science, education, and economy, development of innovative entrepreneurship, commercialization of scientific innovations, digitalization of products and enterprises are among the current issues. Stimulation of innovation activity, an increase of efficiency of scientific innovations, an increase of innovation, an increase of weight of science, scientific-innovative activity in the country's GDP are of special importance for deepening the integration of science with economic and business processes in Azerbaijan. The study of different approaches to the analysis of the components of the National Innovation System helps to identify the potential for commercialization of innovations in a timely manner. Evaluation of the system of initial indicators characterizing the process of commercialization of scientific innovations, the composite index of commercialization potential, and the indices that form it provide a basis for the effective use of financial allocations for scientific research. The commercialization of scientific innovation products necessitates the development and application of preventive recommendations for the transformation of inventions, patents, know-how into knowledge and commercial products. Taking into account the requirements of modern ICT technologies, the main trends of the 4.0 Industrial Revolution, the identification of problems in the development of commercialization of scientific innovations can significantly contribute to the effective management of commercialization of research results and apply appropriate institutional and financial mechanisms. 
In order to increase the efficiency of the commercialization process, the formation of the infrastructure of the National Innovation System and the process of information support system should be approached on the basis of the latest achievements of modern ICT technologies and tools. For the commercialization of research results and innovation processes, a single information space should be developed and applied between the databases of relevant innovation participants. In the future, the implementation of the process on the basis of statistical and expert information in specific conditions and situations and the adoption of appropriate decisions can stimulate overall economic development.

\section{References}

1. Нижегородцев Р.М. Перспективы инновационного развития: институты и механизмы экономической политики // Друкеровский вестник. 2019. № 6. С. 214-226.

2. Decree of the President of the Republic of Azerbaijan on improving governance in the field of digital transformation. Baku, april 27, 2021. https://president.az/articles/51299.

3. The Sustainable Development Goals Report 2020, United Nations, https://unstats.un.org/sdgs/report/2020/.

4. Schwab K. The Fourth Industrial Revolution. Ginebra: World Economic Forum, 2016. $192 \mathrm{p}$.

5. "Azerbaijan 2030: National Priorities for Socio-Economic Development" and the Order of the President of the Republic of Azerbaijan on its approval, Baku, february 2, 2021, https://president.az/articles/50474.

6. Strategic Roadmap for the Development of Telecommunications and Information Technologies. Baku, december 6, 2016, https://president.az/articles/22382.

7. Decree of the President of the Republic of Azerbaijan on the establishment of the "Technology Commercialization and Transfer Center" under the Intellectual Property Agency of the Republic of Azerbaijan, Baku, april 6, 2021. https://president.az/articles/51024.

8. Law of the Republic of Azerbaijan "On Science". Baku, june 14, 2016, http://science.gov.az/uploads/PDF/Elm_haqqinda_Azerb_Respublikasinin_Qanunu.pdf.

9. Development program of ANAS for 2020-2025. December 28, 2019, http://elm.az/uploads/pdf/p1dvqo29ke1r0u187d5at1k1b13e44.pdf.

10. OECD Science. Technology and Innovation Outlook 2021. https://www.oecd.org/sti/oecd-science-technology-and-innovation-outlook-25186167.htm.

11. Martinez-Ros E. Revisiting product and process innovations // International Journal of Business Environment. 2019. Volume 10. Issue 3. P. 270-280.

12. Alguliyev R.M., Aliyev A.G., Shahverdiyeva R.O. The content of innovations and structural analysis of their features in the formation of information economy // Life Science Journal. 2014. Vol. 11. No. 12. P. 119-125.

13. Nizhegorodtsev R.M., Sekerin V.D., Goroxova A.E., Goridko N.P. Features of innovation management strategies in the post-industrial economy // Academy of Strategic Management Journal. 2017. Volume 16. Special Issue 2. P. 1-8.

14. Huseynova A.D. Science and innovation activities: measurement and evaluation. Baku, 2020, 374 p.

15. Lebedev A.L., Sekerin V.D., Semikova O.R., Gorokhova A.E. Management of innovative activities in the organization. Moscow, Scientific consultant, 2018. 272 p. 
16. Shcherbakov V.N., Dubrovsky A.V., Makarova I.V. Macroeconomic aspects of commercialization of innovations. Monograph, Moscow, 2020. 492 p.

17. Aliyev A.G. Development of models and mechanisms of commercialization stage in innovation processes // News of ANAS. Science and Innovation Series. 2012. № 3 (11). P. 3-11.

18. Tikhomirova O.G. Diffusion of innovations, technology transfer and commercialization of innovations // Fundamental Research. 2018. No. 1. P. 127-132.

19. Черных С. И., Фролова Н.Д. и др. Зарубежный опыт финансирования исследований и разработок и возможности его применения в России, Москва, ИПРН РАН, 2020. $201 \mathrm{c}$.

20. Нугуманова Г.Р. Разработка модели коммерциализации инноваций для формирования инновационной системы в России // Креативная экономика. 2020. Том 12. № 12. C. 1929-1938.

21. Сальникова К.В. Коммерциализация результатов научных исследований и разработок в условиях цифровой экономики// Социально-экономическое развитие России: Проблемы, тенденции, перспективы: Сборник статей XVIII Международной научнопрактической конференции, 25 июня 2019 г. С. 297-304.

22. EC. European Innovation Scoreboard, Luxembourg, Publications Office of the European Union, 2020. $98 \mathrm{p}$.

23. OECD. Business innovation statistics and indicators, 2019. https://www.oecd.org/innovation/inno/inno-stats.htm\#indicators.

24. Kanivets P.I., Kurushina O.P. Methodology for expert analysis and assessment of the rating of the prospects for the commercialization of scientific and technical developments // Izvestiya KBSC RAS. 2009. No. 2 (28). P. 61-71.

25. Karpycheva S.A. Development of an algorithm for the commercialization of developments in scientific organizations // Vestn. Moscow University. Series 6, Economics. 2017. No. 5. P. 125-144.

Поступила в редакиию 20.08.2021

Алиев Аловсат Гараджа оглы - кандидат экономических наук, доцент, заведующий отделом Института Информационных технологий, Национальная Академия наук Азербайджана, Азербайджан.

Aliyev Alovsat Garaja - PhD. in Economics, Institute of Information Technology of Azerbaijan National Academy of Sciences.

AZ1141, Azerbaijan Republic, Baku, B.Vahabzade str., 9A

9A, B.Vahabzade str, Baku, AZ1141, Azerbaijan Republic e-mail: alovsat_qaraca@mail.ru 